\title{
ECOFRIENDLY ADSORBENT FROM FOOD WASTE FOR WATER PURIFICATION
}

\author{
K.S. Beena Kumari ${ }^{1} \square$ (D), S. Mary Paulin ${ }^{2}$ \\ ${ }^{1}$ Department of Chemistry, All Saints' College, University of Kerala, Thiruvananthapuram, Kerala. 695007, \\ India \\ ${ }^{2}$ Department of Chemistry, S.N. College, Chengannur, Kerala, India
}

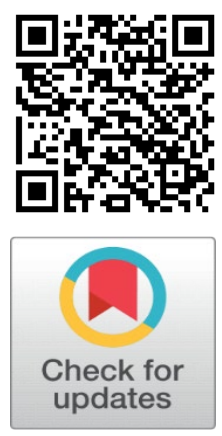

\section{ABSTRACT}

Egg shell, which is a waste material emerging out in large quantities from poultries, homes and restaurants, may be used as a good adsorbent for heavy metals. Different types of eggshells were used in this study for the adsorption of a major pollutant such as iron from surface water. Effect of $\mathrm{CaCO} 3$ content in the egg shell, particle size, contact time, temperature and shaking on adsorption were also studied. The adsorption isotherms fitted by the Langmuir model revealed that the adsorption of iron by eggshell samples was monolayer adsorption.

Received 1 September 2021

Accepted 13 September 2021

Published 30 September2021

\section{CorrespondingAuthor}

K.S. Beena Kumari,

beenagireesh@yahoo.co.uk

DOI

10.29121/granthaalayah.v9.i9.2021. 4230

Funding: This research received no specific grant from any funding agency in the public, commercial, or not-for-profit sectors.

Copyright: (C) 2021 The Author(s). This is an open access article distributed under the terms of the Creative Commons Attribution License, which permits unrestricted use, distribution, and reproduction in any medium, provided the original author and source are credited.

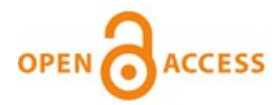

Keywords: Adsorbent, Isotherm, Heavy Metals, Porosity

\section{INTRODUCTION}

Industrial effluents, greenhouse effect, pharmaceutical products, volatile organic compounds, biological contamination, Radiological elements and many human activities contaminated rivers and lakes making the environmental conservation a difficult task Ghrefat et al. (2014), Cooper and Harrison (2009), Pal et al.(2014), Alireza et al. (2010). There are several methods for the purification of water like ion exchange Alexandratos (2009), Strathmann (2010), membrane treatment Charcosset (2009), reverse osmosis Park and Hu (2010), use of biologically active carbon filtration Branda et al. (2005), magnetic separation Jianxin et al. (2007) and adsorption using chemical adsorbents Jiuhui (2008), Chen et al. (1987), Rahman et al. (2012). All these methods were costly and not environmentally friendly. There were studies using natural adsorbents like clays, mustard oil, neem leaves, mango and eucalyptus leaves etc Karthik et al. (2015), Nargawe et al. (2016), Ibtissem and Malikai (2015) for waste water treatment. Investigations are going on to explore useful applications of natural food waste.

Egg shell is the waste material emerging out in large quantities from poultries, homes, restaurants, bakeries etc. Its disposal is always a challenge to the concerned authorities. Researches revealed that eggshells may be used as a fertilizer and a good adsorbent for heavy metals and organic compounds Chojnacka (2005), Rais and Shaziya (2012), Ziad and Madhloom (2016), Misau et al. (2012), Agarwal and Gupta (2014), Nasir et al. (2016), Alok et al. (2016) Egg shell contains carbonates, sulphates and phosphates of calcium and magnesium along with other organic and inorganic matters Tsai et al. (2006), Nakano (2003), Balaz (2014). Surface analysis of egg shell indicates the porous nature and therefore can also be used as effective adsorbent. Thus, use of egg shell as adsorbent is cost effective as well as help in the removal of hazardous chemicals. 
In recent years, chemically modified adsorbents have attracted considerable attention. In this work, different types of eggshells were used for the adsorption of a major pollutant such as iron from surface water. Effect of $\mathrm{CaCO} 3$ content in the egg shell, particle size, contact time, temperature and shaking on adsorption were also studied.

\section{EXPERIMENTAL METHODS}

The reagents used in this study were of analytical grade.

\subsection{PREPARATION OF EGGSHELL SAMPLES}

Eggs of duck, kaada hen, local hen, and broiler hen were bought from the markets of Pulluvila and Kanjiramkulam areas of Thiruvananthapuram district. Collected eggshells were cleaned with distilled water and dried for three hours in sunlight. These eggshells were powdered using a pestle and mortar. The eggshell powder was sieved to collect different particle sizes of area $0.1377 \mathrm{~cm} 2,0.174 \mathrm{~cm} 2$ and $0.1974 \mathrm{~cm} 2$.

\subsection{DETERMINATION OF CACO3 CONTENT IN EGG SHELL}

The Major component of eggshell is calcium carbonate (CaCO3), which was estimated volumetrically. 0.50 grams of each type of eggs shell powder was weighed into a $250 \mathrm{ml}$ conical flask and five drops of ethanol was added to the flask to activate dissolution of eggshell. $10 \mathrm{ml}$ of $1 \mathrm{M} \mathrm{HCl}$ was added to into each flask. Conical flasks were kept for about 24 hours for the complete dissolution of the eggshells. 2-3 drops of phenolphthalein were added. Each one was titrated against $0.5 \mathrm{M} \mathrm{NaOH}$ solution. The titre value gives the amount of unreacted $\mathrm{HCl}$. From this value, percent of $\mathrm{CaCO} 3$ was determined.

\subsection{PREPARATION OF IRON CONTAMINATED WATER}

$10 \mathrm{mg}$ of A.R ferric alum was dissolved in one litre distilled water to prepare 1 ppm of iron solution. $300 \mathrm{ml}$ of this iron solution was diluted to $1000 \mathrm{ml}$ to prepare iron contaminated water which contains iron above $0.3 \mathrm{ppm}$ which is the acceptable limit of iron in potable water.

\subsection{PREPARATION OF STANDARD SOLUTIONS OF IRON}

$0.864 \mathrm{~g}$ of A.R. ferric alum was weighed accurately into $100 \mathrm{ml}$ standard flask and dissolved in distilled water. The solution was acidified with $10 \mathrm{ml}$ of conc. $\mathrm{HCl}$ and then made up to $100 \mathrm{ml} .10 \mathrm{ml}$ of this solution was pipetted out into another standard flask and made up to $100 \mathrm{ml}$.This solution contains $100 \mathrm{ppm}$ iron.

$0.1 \mathrm{ppm}, 0.2 \mathrm{ppm}, 0.3 \mathrm{ppm}, 0.5 \mathrm{ppm}, 1 \mathrm{ppm}, 2 \mathrm{ppm}$ of iron solutions were prepared by transferring $10 \mathrm{ml}, 20 \mathrm{ml}, 30 \mathrm{ml}, 50 \mathrm{ml}, 1 \mathrm{ml}, 2 \mathrm{ml}$ of $100 \mathrm{ppm}$ iron solution into different $100 \mathrm{ml}$ standard flasks. To these standard flasks, $5 \mathrm{ml} 4 \mathrm{~N} \mathrm{HCl}$ and $10 \mathrm{ml} 20 \%$ ammonium thiocyanate solutions were added and then made up to $100 \mathrm{ml}$. A blank solution was prepared using only the reagents $5 \mathrm{ml}$ of $4 \mathrm{~N} \mathrm{HCl}$ and $10 \mathrm{ml} 20 \%$ ammonium thiocyanate in $100 \mathrm{ml}$ distilled water. The absorbance values of prepared samples were measured using Systronics Double Beam Spectrophotometer 2203 with a filter of $490 \mathrm{~nm}$. 


\subsection{EFFECT OF PARTICLE SIZE OF EGG SHELL POWDER ON ADSORPTION OF IRON FROM WATER}

$10 \mathrm{ml}$ of iron contaminated water was taken in each of twelve $50 \mathrm{ml}$ beaker. To this $0.5 \mathrm{~g}$ each of different types of eggshells (Kaada hen, Local hen, Broiler hen, Duck) having particle sizes $0.1377 \mathrm{~cm} 2,0.174 \mathrm{~cm} 2$ and $0.1974 \mathrm{~cm} 2$ were added. Iron solutions with egg shells were kept at room temperature at about 280C for 24 hours. Absorbance values of the filtered samples were measured to estimate the amount of iron removed by the adsorbent.

\subsection{EFFECT OF CONTACT TIME}

$0.5 \mathrm{~g}$ of eggshell samples each of broiler hen and local hen of particle size $0.174 \mathrm{~cm} 2$ were taken in two $50 \mathrm{ml}$ beakers with $10 \mathrm{ml}$ of iron contaminated water. Absorbance value of each solution was determined at 15, 30, 45, 60, 75, 90,105, 120, 135,150 minutes.

\subsection{EFFECT OF TEMPERATURE ON ADSORPTION OF IRON}

$0.5 \mathrm{~g}$ each of broiler hen eggshell powder having particle size of $0.174 \mathrm{~cm} 2$ were taken in four $50 \mathrm{ml}$ beakers. $10 \mathrm{ml}$ of iron contaminated water was added to each beaker. Adsorption studies were conducted at 30o, 40o, 50o and 90oC respectively using a water bath. Absorbance values were measured after conducting the experiment.

\subsection{EFFECT OF SHAKING ON ADSORPTION OF IRON}

$0.5 \mathrm{~g}$ eggshell powder of broiler hen and local hen with particle sizes $0.174 \mathrm{~cm} 2$ were taken in two $100 \mathrm{ml}$ conical flasks and to these $10 \mathrm{ml}$ of iron contaminated water were added. The samples were shaken for one hour at $150 \mathrm{rpm}$ and $300 \mathrm{rpm}$ speed in an electric shaker Rivotek and then kept 5 minutes at rest to attain stability. The absorbance values of the filtered samples were measured.

\section{RESULT AND DISCUSSION}

\section{Calcium Carbonate Determination}

$0.5 \mathrm{~g}$ each of eggshell samples dipped in $10 \mathrm{ml} 1 \mathrm{M} \mathrm{HCl}$ for 24 hours. The unreacted $\mathrm{HCl}$ is titrated against $0.5 \mathrm{M} \mathrm{NaOH}$. From the titre values, the weight of $\mathrm{CaCO} 3$ and its percentage in each eggshell were calculated and given in Figure 1.

\section{PERCENTAGE OF $\mathrm{CaCO}_{3}$}

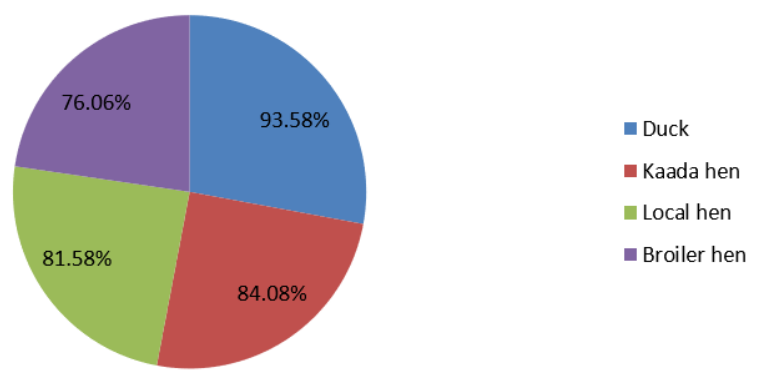

Figure 1 Diagramatic representation of percentage of CaCO3 
This diagram showed that the percentage of $\mathrm{CaCO} 3$ decreases in the order,

Duck > Kaada hen $>$ Local hen $>$ Broiler hen

\section{Determination of Iron Content}

The absorbance values of the standard iron solutions were measured and are given in Table 1.

\begin{tabular}{|cc|}
\hline Table 1 Absorbance given by standard iron solutions \\
\hline Iron Concn. (ppm) & Absorbance \\
\hline 0.1 & 0.045 \\
\hline 0.2 & 0.074 \\
\hline 0.3 & 0.099 \\
0.5 & 0.157 \\
\hline 1.0 & 0.332 \\
\hline
\end{tabular}

\section{Adsorption of Iron by Eggshells}

Eggshells of particle size $0.1377 \mathrm{~cm} 2,0.174 \mathrm{~cm} 2$ and $0.1974 \mathrm{~cm} 2$ were prepared and dipped in iron contaminated water for $24 \mathrm{Hrs}$. The absorbance values of samples after adsorption study were noted and are given in Table 2.

\begin{tabular}{|ccc|c|}
\hline Table 2 Absorbance values of samples after treatment by eggshells of different particle size \\
\hline \multicolumn{3}{c|}{ Particle Size } \\
\hline Egg shell Samples & $\mathbf{0 . 1 3 7 7}\left(\mathbf{c m}^{2}\right)$ & $\mathbf{0 . 1 7 4}\left(\mathbf{c m}^{2}\right)$ & $\mathbf{0 . 1 9 7 4}\left(\mathbf{c m}^{2}\right)$ \\
Duck & 0.074 & 0.055 & 0.075 \\
Kaada Hen & 0.036 & 0.030 & 0.034 \\
Local Hen & 0.032 & 0.025 & 0.036 \\
\hline Broiler hen & 0.036 & 0.022 & 0.030 \\
\hline
\end{tabular}

From Table 2, it was observed that, among all these eggshell samples, maximum adsorption was shown in the particle size $(0.174 \mathrm{~cm} 2)$. Broiler hen eggshells showed greater iron adsorption than all other samples. Least adsorption was shown by eggshell of duck in all particle sizes. Adsorption efficiency of eggshell samples decrease in the order,

Broiler Hen > Local Hen > Kaada Hen > Duck

\section{Effect of Contact Time}

$0.5 \mathrm{~g}$ of eggshell samples each of broiler hen and local hen of particle size of $0.174 \mathrm{~cm} 2$ which showed maximum adsorption capacity were taken in two $50 \mathrm{ml}$ beakers with $10 \mathrm{ml}$ of iron contaminated solution. Adsorption study was conducted determined by varying contact time from 15 to150min. Absorbance values after adsorption is given in Table 3. 


\begin{tabular}{lcc}
$\begin{array}{l}\text { Table } 3 \text { Absorbance value given by broiler and local eggshell samples at different contact } \\
\text { time }\end{array}$ & Absorbance \\
\hline Contact time & Broiler Hen & Local Hen \\
\hline (min) & 0.075 & 0.087 \\
15 & 0.054 & 0.063 \\
30 & 0.032 & 0.049 \\
45 & 0.022 & 0.025 \\
60 & 0.020 & 0.023 \\
\hline 75 & 0.018 & 0.020 \\
\hline 105 & 0.015 & 0.020 \\
\hline 120 & 0.015 & 0.025 \\
\hline 150 & 0.016 & 0.030 \\
\hline
\end{tabular}

Table 3 shows that adsorption of iron increased with contact time up to 105 minutes for broiler eggshell and 90 min for local hen eggshell. Further increase in contact time did not enhance the iron adsorption process. The adsorption process attained equilibrium at 105 and 90 minutes on the surface of broiler and local hen eggshell samples respectively. The fast adsorption rate at the initial stage may be explained by the increase in availability of the number of active binding sites on the adsorbent surface. After the saturation point, there is no further increase in the rate of adsorption.

\section{Effect of Temperature on Adsorption}

$0.5 \mathrm{~g}$ each of broiler hen eggshell having particle size $0.174 \mathrm{~cm} 2$ (best adsorbent obtained) were taken in four $50 \mathrm{ml}$ beakers containing $10 \mathrm{ml}$ iron contaminated solution. Adsorption study was conducted at different temperatures $(30,40,50$ and 900C) using a water bath for one hour. The resultant absorbance values obtained are given in Table 4.

Table 4 Absorbance value given by broiler hen eggshell samples at different temperatures

\begin{tabular}{cc} 
Temperature $\left({ }^{\circ} \mathbf{C}\right)$ & Absorbance \\
28(room temperature) & 0.022 \\
30 & 0.011 \\
40 & 0.057 \\
50 & 0.034 \\
90 & 0.044 \\
\hline
\end{tabular}


From Table 4, it is observed that, the adsorption rate decreases when the temperature increases above $30 \mathrm{oC}$. This can be explained due to the increase in pore size of the adsorbent and increase in the kinetic energy of the adsorbate molecule with rise in temperature. After $30 \mathrm{oC}$, pore size of adsorbent increase above the size of adsorbate molecule and as a result the adsorbate will move out of the surface of adsorbent.

\section{Effect of Shaking}

$0.5 \mathrm{~g}$ of eggshell samples of broiler hen and local hen of particle size $0.174 \mathrm{~cm} 2$ were taken in two $100 \mathrm{ml}$ conical flasks along with $10 \mathrm{ml}$ of iron contaminated solution. Absorbance was determined after shaking the samples at $150 \mathrm{rpm}$ and 300 rpm speed for about 1 hours and attaining steady state is given in Table 5 .

\begin{tabular}{|c|c|c|}
\hline \multirow[t]{3}{*}{ Sample } & \multicolumn{2}{|c|}{ Absorbance } \\
\hline & \multicolumn{2}{|c|}{ Shaking Speed } \\
\hline & 150rpm & 300rpm \\
\hline Broiler Hen & 0.017 & 0.010 \\
\hline Local Hen & 0.022 & 0.021 \\
\hline
\end{tabular}

Table 5 showed that iron adsorption increases with agitation at $150 \mathrm{rpm}$ speed. The reason for the increase in adsorption is that, better contact between the adsorbent and adsorbate takes place at higher speed. But after a particular limit ie; at $300 \mathrm{rpm}$, there is a probability of removal of adsorbate from the adsorbent surface.

\section{Isothermal Studies}

\section{Freundlich isothermal studies}

The Freundlich isothermal studies were conducted using the absorbance value of Table 2. The Freundlich isothermal equation is given by, $\log x / m=\log k+(1 / n)$ $\log \mathrm{c}$ where $\mathrm{x}$ is mass of adsorbate adsorbed, $\mathrm{m}$ is mass of adsorbent, $\mathrm{k} \& \mathrm{n}$ are Freundlich constants and $\mathrm{C}$ is the equilibrium concentration of adsorbate. Freundlich parameters were calculated and are given in Table 6.

\begin{tabular}{|c|c|c|c|c|c|c|c|}
\hline \multicolumn{8}{|c|}{ Table 6 Freundlich isothermal studies } \\
\hline \multicolumn{2}{|c|}{ Samples } & \multirow{2}{*}{$\begin{array}{c}\mathbf{x} \\
0.05\end{array}$} & \multirow{2}{*}{$\begin{array}{c}\mathbf{m} \\
0.50\end{array}$} & \multirow{2}{*}{$\begin{array}{c}\mathbf{x} / \mathbf{m} \\
0.1\end{array}$} & \multirow{2}{*}{$\begin{array}{c}\log (\mathbf{x} / \mathbf{m}) \\
-0.8538\end{array}$} & \multirow{2}{*}{$\begin{array}{c}\text { C } \\
0.25\end{array}$} & \multirow{2}{*}{$\begin{array}{c}\log C \\
-0.6382\end{array}$} \\
\hline Kaada Hen & $0.1377 \mathrm{~cm}^{2}$ & & & & & & \\
\hline & $0.174 \mathrm{~cm}^{2}$ & 0.13 & 0.50 & 0.26 & -0.5850 & 0.17 & -0.7695 \\
\hline & $0.1974 \mathrm{~cm}^{2}$ & 0.07 & 0.50 & 0.14 & -0.8538 & 0.23 & -0.6382 \\
\hline \multirow[t]{3}{*}{ Local Hen } & $0.1377 \mathrm{~cm}^{2}$ & 0.20 & 0.50 & 0.4 & -0.3979 & 0.10 & -1 \\
\hline & $0.174 \mathrm{~cm}^{2}$ & 0.23 & 0.50 & 0.46 & -0.3372 & 0.07 & -1.1549 \\
\hline & $0.1974 \mathrm{~cm}^{2}$ & 0.18 & 0.50 & 0.36 & -0.4436 & 0.12 & -0.9208 \\
\hline
\end{tabular}




\begin{tabular}{cccccccc} 
Broiler Hen & $0.1377 \mathrm{~cm}^{2}$ & 0.18 & 0.50 & 0.36 & -0.4436 & 0.12 & -0.9208 \\
& $0.174 \mathrm{~cm}^{2}$ & 0.25 & 0.50 & 0.50 & -0.3010 & 0.05 & -1.3010 \\
& $0.1974 \mathrm{~cm}^{2}$ & 0.21 & 0.50 & 0.42 & -0.3767 & 0.09 & -1.0457 \\
\multirow{2}{*}{ Duck } & $0.1377 \mathrm{~cm}^{2}$ & 0.19 & 0.50 & 0.38 & -0.4202 & 0.11 & -0.9586 \\
& $0.174 \mathrm{~cm}^{2}$ & 0.21 & 0.50 & 0.42 & -0.3767 & 0.09 & -1.0457 \\
& $0.1974 \mathrm{~cm}^{2}$ & 0.20 & 0.50 & 0.4 & -0.3979 & 0.10 & -1
\end{tabular}

From Table 6, using calculated values of $(\mathrm{x} / \mathrm{m})$ on $\mathrm{Y}$-axis and $\mathrm{C}$ on $\mathrm{X}$-axis, Freundlich adsorption isotherms were drawn for the adsorption of iron by each eggshell samples and are shown in Figure 2.
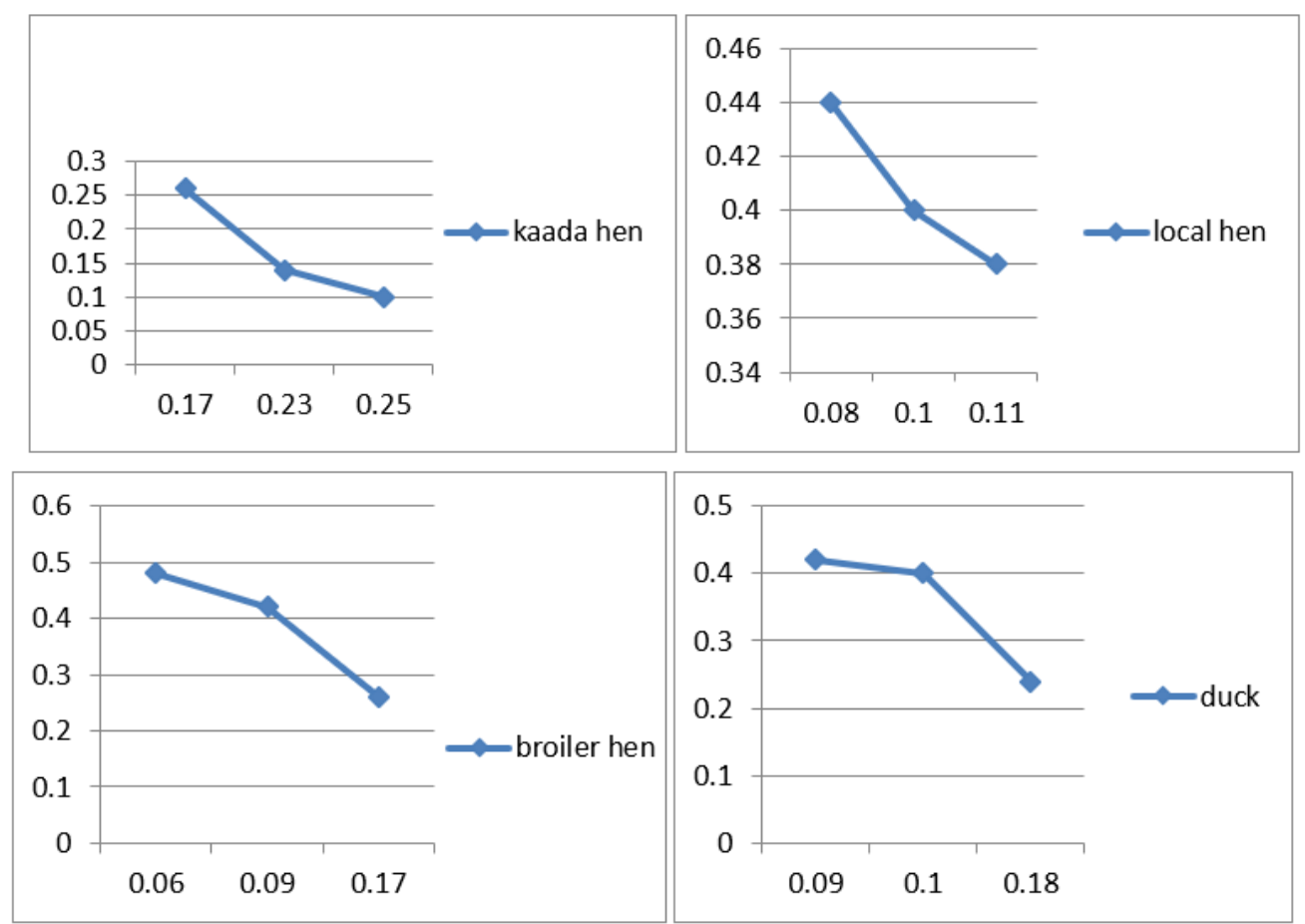

Figure 2 Freundlich adsorption isotherms for different egg shell samples

In Freundlich adsorption isotherm nonlinear plot was obtained, which reveal the non-applicability of this isotherm. This showed that adsorption of the iron by these eggshell samples was not multilayer adsorption. This indicates that there is no stacking of adsorbed molecules. Pores on the surface of eggshell adsorb iron only on single layer and do not allow the adsorption on the second layer.

\section{Langmuir isothermal studies}

The Langmuir isothermal studies were conducted using the absorbance value of Table 2. The Langmuir isothermal equation is given by, Ce/qe $=(1 / \mathrm{KLQm})+$ $(\mathrm{Ce} / \mathrm{Qm})$ where, Ce is equilibrium concentration of adsorbate, qe amount of adsorption at equilibrium, $\mathrm{Qm}$ is monolayer adsorption capacity and KL is Freundlich constant.The Langmuir parameters were calculated and are given in Table 7. 


\begin{tabular}{|c|c|c|c|c|}
\hline \multicolumn{5}{|c|}{ Table 7 Langmuir isothermal studies } \\
\hline \multicolumn{2}{|c|}{ Samples } & \multirow{2}{*}{$\begin{array}{c}\text { Ce } \\
0.25\end{array}$} & \multirow{2}{*}{$\begin{array}{c}\mathbf{q}_{\mathrm{e}} \\
0.001\end{array}$} & \multirow{2}{*}{$\begin{array}{c}\mathbf{C e} / \mathbf{q}_{\mathbf{e}} \\
250\end{array}$} \\
\hline Kaada Hen & $0.1377 \mathrm{~cm}^{2}$ & & & \\
\hline & $0.174 \mathrm{~cm}^{2}$ & 0.17 & 0.0026 & 65.38 \\
\hline & $0.1974 \mathrm{~cm}^{2}$ & 0.23 & 0.0014 & 164.28 \\
\hline \multirow[t]{3}{*}{ Local Hen } & $0.1377 \mathrm{~cm}^{2}$ & 0.10 & 0.004 & 25 \\
\hline & $0.174 \mathrm{~cm}^{2}$ & 0.07 & 0.0046 & 15.21 \\
\hline & $0.1974 \mathrm{~cm}^{2}$ & 0.12 & 0.0036 & 33.33 \\
\hline \multirow[t]{3}{*}{ Broiler Hen } & $0.1377 \mathrm{~cm}^{2}$ & 0.12 & 0.0036 & 33.33 \\
\hline & $0.174 \mathrm{~cm}^{2}$ & 0.05 & 0.005 & 10 \\
\hline & $0.1974 \mathrm{~cm}^{2}$ & 0.09 & 0.0042 & 21.43 \\
\hline \multirow[t]{3}{*}{ Duck } & $0.1377 \mathrm{~cm}^{2}$ & 0.11 & 0.0038 & 28.94 \\
\hline & $0.174 \mathrm{~cm}^{2}$ & 0.09 & 0.0042 & 21.43 \\
\hline & $0.1974 \mathrm{~cm}^{2}$ & 0.10 & 0.004 & 25 \\
\hline
\end{tabular}

From Table 7, using calculated values of Ce/qe on Y-axis and Ce on X-axis, Langmuir adsorption isotherms were drawn for the adsorption of iron by each eggshell samples and are shown in Figure 3.
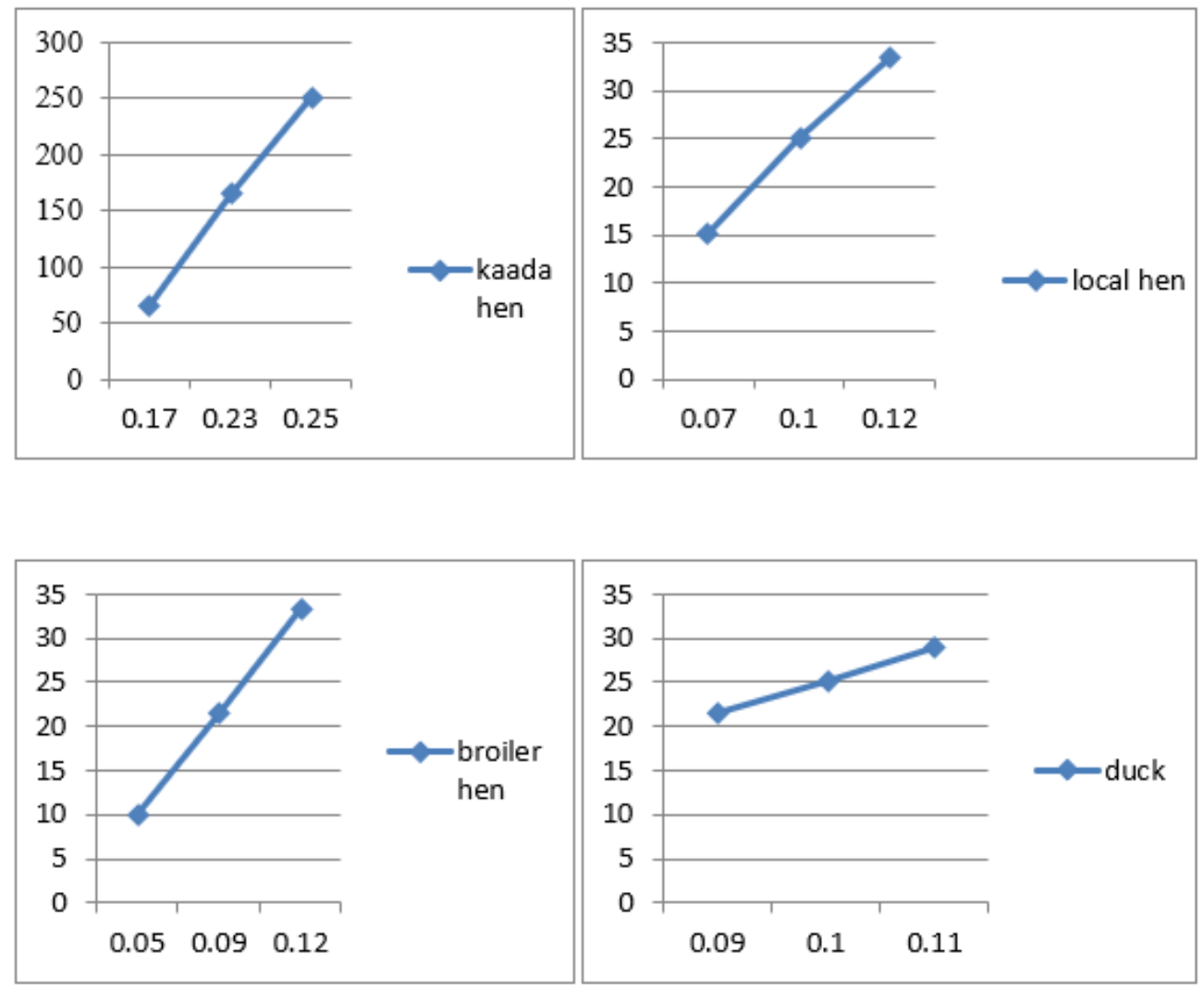

Figure 3 Langmuir adsorption isotherm graphs for different egg shell samples 
A linear plot was obtained for Langmuir adsorption isotherms of all the eggshells samples which showed its applicability. In this study, monolayer adsorption of iron by eggshell samples was taken place.

The removal of iron from the polluted water by the application of powdered eggshell samples took place by physisorption. There is no multilayer adsorption happening due to the absence of chemical bonding between the adsorbent and adsorbate molecules. This process is found to be very good eco-friendly method for water treatment.

The simplest and still the most useful isotherm, for both physical and chemical adsorption, is the Langmuir isotherm. This model assumes that adsorption is limited to a monolayer. Only a single layer of molecule on the eggshell surface was adsorbed due to the homogeneous nature of eggshell surface. The energy of adsorption is uniform for all sites. Similar to the reported studies Reyhaneh et al. (2015), there is no interaction between iron molecules adsorbed on neighboring sites. As a result, the tendency to form multilayer adsorption is less.

\section{CONCLUSION}

Efficient removal of heavy metal ions from wastewater is of extreme important due to the occurance of large number of toxic organic and inorganic pollutants water bodies. Low cost, high efficiency and biodegradable nature of the adsorbents made adsorption an eco-friendly and clean technology. It helps in the removal of heavy metals present in low concentration. Eggshell powder is a cheap, natural adsorbent material used for removal of different heavy metals from water by adsorption which becomes a solution for the increasing eggshell waste now a day. The parameters used in this study gave certain information about their effects on adsorption of iron from water. This work reveals that eggshell containing least amount of calcium carbonate showed greater adsorption capacity. Eggshell samples having particle size $0.174 \mathrm{~cm} 2$ showed higher adsorption rate than the other two particle sizes used in this work. Adsorption process has inverse relation with temperature and direct relation with contact time. Shaking process is a good method for increasing the adsorption rate. This work confirmed that eggshell is an excellent substitute to commercial and nonrenewable adsorbents to remove toxic heavy metal like iron in water resource efficiently. The adsorption isotherms fitted by the Langmuir model revealed that the adsorption of iron by eggshell samples was monolayer adsorption and only physisorption occurs on the surface of eggshell.

\section{REFERENCES}

Alexandratos, S.D (2009) Ion-exchange resins: a retrospective from industrial and engineering chemistry research. Ind. Eng. Chem. Res., 48(1)388-398. Retrieved from https://doi.org/10.1021/ie801242v

Alireza, B. Mohammadi, S. Mowlavi A.and Parvaresh, P (2010) Measurement of heavy radioactive pollution: radon and radium in drinking water samples in Mashhad. Int. J. Curr. Res., 10 54-58. Retrieved from https://www.researchgate.net/profile/Ali-Mowlavi-

2/publication/228466661_Measurement_of_heavy_radioactive_pollution_r adon_and_radium_in_drinking_water_samples_of_Mashhad/links/0c96051 ddaf910e3a0000000/Measurement-of-heavy-radioactive-pollution-radonand-radium-in-drinking-water-samples-of-Mashhad.pdf 
Alok, M. Soni, R.K. Meenu T. and Jyoti, M (2016) Applications of egg shell and eggshell membrane as adsorbents: A overview. J. Mol. Liq. 377-378.

Animesh Agarwal1 and Puneet Kumar Gupta (2014) Removal of $\mathrm{Cu} \& \mathrm{Fe}$ from aqueous solution by using eggshell powder as low cost adsorbent, Adv. Appl. $\begin{array}{lllll}\text { Sci. } & \text { Res., } & 5(2) & \text { 75-79. } & \text { Retrieved }\end{array}$ https://www.cabdirect.org/cabdirect/abstract/20143228326

Balaz, M (2014) Eggshell membrane biomaterial as a platform for applications in materials science. Acta Biomater. 10 3827-3843. Retrieved from https://doi.org/10.1016/j.actbio.2014.03.020

Branda, S. Vik, A. Friedman L. and Kolter, R (2005) Biofilms: the matrix revisited, Trends Microbiol., 13 20-26. Retrieved from https://doi.org/10.1016/j.tim.2004.11.006

Charcosset, C (2009) A review of membrane processes and renewable energies for desalination. Desalination. 245 214-231. Retrieved from https://doi.org/10.1016/j.desal.2008.06.020

Chen, A.S.C. Snoeyink V.L. and Fiessinger, F (1987) Activated alumina adsorption of dissolved organic compounds before and after ozonation. Environ. Sci. Technol. 21(1) 83-90. Retrieved from https://doi.org/10.1021/es00155a010

Chojnacka, K (2005) Biosorption of Cr (III) ions by eggshells. J. Hazard. Mater. 121 167- 173. Retrieved from https://doi.org/10.1016/j.jhazmat.2005.02.004

Cooper, R.G. and A.P. Harrison (2009) The exposure to and health effects of antimony. Indian J. Occup. Environ. Med. 13(1) 3-10. Retrieved from https://doi.org/10.4103/0019-5278.50716

Ghrefat, H. Nazzal, Y. Batayneh, A. Zumlot, T. Zaman, H. Elawadi, E. Laboun, A. Mogren S. and Qaisy, S (2014) Geochemical assessment of ground water contamination with special emphasizes on fluoride, a case study from Midyan Basin, north Western Saudi Arabia. Environ. Earth Sci. 71 14951505. Retrieved from https://doi.org/10.1007/s12665-013-2554-1

Ibtissem G.A.and Malikai, T.A (2015) Competitive adsorption of heavy metals on local landfill clay. Arabian Journal of Chemistry 8(1) 25-31. Retrieved from https://doi.org/10.1016/j.arabjc.2011.02.030

Jianxin, L. Jingxia, L. Tao Y. and Changfa, X (2007) Quantitative study of the effect of electromagnetic field on scale deposition on nanofiltration membranes via UTDR. Water Res., 41(20) 4595-4610. Retrieved from https://doi.org/10.1016/j.watres.2007.06.041

Jiuhui, Q.U (2008) Research progress of novel adsorption processes in water purification: a review. Int. J. Environ. Sci. 20(1) 1-13. Retrieved from https://doi.org/10.1016/S1001-0742(08)60001-7

Karthik., V. Kamal, B. Mohammed, M. Haneef, V. and Mannarthippusulthan, M.A.M (2015) Removal of dyes and metals using natural adsorbents. J. Chem. Pharm. Res. 7(3) 77-82. Retrieved from https://www.cabdirect.org/cabdirect/abstract/20153176214.

Misau, D. Usman, A.E.N. Surajudeen A. and Yusuf, M.I (2012) Removal of Oil from Oil Produced Water Using Eggshell. Civ. Env. Res., 28.

Nakano, T. Ikawa, N.I. Ozimek, (2003) Chemical composition of chicken eggshell and Shell membranes. Poultry Sci. 82 510-514. Retrieved from https://doi.org/10.1093/ps/82.3.510 
Nargawe, T. Dipak S.and Arti, D( 2016) Utilization of Natural Adsorbents in the Elimination of Toxic Metal Ions in Industrial Effluents: A Review. Asian J. Chem.. 9(2) 70. Retrieved from https://doi.org/10.5958/09744150.2016.00013.4

Nasir, H.M. Azmi, A. Aris1 A.Z. and Praveena, S.M (2016) Adsorption of iron by using hybrid Akar Putra and commercialized chicken eggshells as bio-sorbents from aqueous solution. Glob. J. Environ. Sci. Manag. 2(3) 257-264. Retrieved from https://www.sid.ir/en/journal/ViewPaper.aspx?id=504727

Pal, A. He, Y. Jekel, M. Reinhard M. and Gin, K.Y (2014) Emerging contaminants of public health significance as water quality indicator compounds in the urban water cycle. Environ. Int. 71 46-62. Retrieved from https://doi.org/10.1016/j.envint.2014.05.025

Park S.K and Hu, J.Y (2010) Assessment of the extent of bacterial growth in reverse osmosis system for improving water quality. J Environ Sci Heal A 45(8) 968977. Retrieved from https://doi.org/10.1080/10934521003772386

Rahman, M.M. Awang M.B.and Yusof, 'A.M (2012) Preparation, characterization and application of zeolite-Y (Na-Y) for water filtration', Aust. J. Basic \& Appl. Sci. 6(1) 50-54

Rais, A. Rajeev K. and Shaziya, H (2012) Adsorption of Cu2+ from aqueous solution onto iron oxide coated eggshell powder: Evaluation of equilibrium, isotherms, kinetics, and regeneration capacity. Arab. J. Chem.5(3) 353-359. Retrieved from https://doi.org/10.1016/j.arabjc.2010.09.003

Reyhaneh, S. Zahra, S. Reza, F. and Narges, E.F (2015) Monolayer and multilayer adsorption isotherm models for sorption from aqueous media. Korean J. Chem. Eng. 32(5) 787-799. Retrieved from https://doi.org/10.1007/s11814-015-0053-7

Strathmann, H (2010) Ion-exchange membrane processes in water treatment. Sustain Sci Eng. 2(9) 141-199. Retrieved from https://doi.org/10.1016/S1871-2711(09)00206-2

Tsai, W.T. Yang, J.M. Lai, C.W. Cheng, Y.H. Lin C.C. and Yeh, C.W (2006) Characterization and adsorption properties of eggshells and eggshell membrane. Bioresour. Technol. 97 488-493. Retrieved from https://doi.org/10.1016/j.biortech.2005.02.050

Ziad, T.A.A. Mohammed, A.I.and Madhloom, H (2016) Eggshell powder as an adsorbent for removal of $\mathrm{Cu}$ (II) and Cd (II) from aqueous solution: Equilibrium, kinetic and thermodynamic studies. Al-Nahrain Univ., Col. of Eng. J. $19 \quad 186 \quad-\quad 193 . \quad$ Retrieved from https://nahje.com/index.php/main/article/view/12 